\title{
Transcription Factor E2F2
}

National Cancer Institute

\section{Source}

National Cancer Institute. Transcription Factor E2F2. NCI Thesaurus. Code C96003.

Transcription factor E2F2 (437 aa, $\sim 48 \mathrm{kDa}$ ) is encoded by the human E2F2 gene. This protein plays a role in the mediation of both cell cycle progression and transcription. 